\title{
GROUND WATER IN BIG SMOKY VALLEY, NEVADA.
}

\author{
By O. E. Meinzer.
}

\section{INTRODUCTION.}

\section{GROUND WATER FOR IRRIGATION IN NEVADA.}

The agricultural conquest of vast areas of arable land belonging to the public domain of the United States-the conversion of these apparently boundless expanses of Government land into hundreds of thousands of productive farms: and well-provided homes within the last few decades - forms a brilliant chapter in the history of this country. A consideration of this marvelous agricultural development leads at once, however, to a serious problem of the not distant future. Only a few years ago the supply of agricultural land in the great West was commonly assumed to be inexhaustible; to-day the country is beginning to realize that virtually all the tracts which can readily be made productive without irrigation have been occupied and that practically all the streams which can be utilized for irrigation without the installation of expensive storage projects have been appropriated. Moreover, in comparison with the rapid progress in the past, the limits of agricultural development, even with the greatest possible conservation of soil and water and the application of the best cultural methods, appear to be not indefinitely remote. But the realization in recent years of the fact that the part of the public domain which has value for agriculture is rapidly being taken up has itself provided a powerful motive for further acquisition of agricultural land and has induced men and women eager for farms and homes of their own to settle in large numbers in areas where the conditions are so unfavorable or so poorly understood that failure and suffering are inevitable.

In Nevada the bedrock forms a corrugated surface consisting of - more or less parallel mountain ranges and broad intervening troughs that are filled to great depths with rock waste washed from the mountains. These great deposits of rock waste were in large part laid down by torrential streams and are relatively coarse and porous. Because they are porous they allow the rain that falls upon them and the run-off that reaches them from the mountains to sink into them, and consequently the desert valleys which they underlie have 
an exceptionally arid aspect. These deposits are, however, great water conservers, for they constitute huge reservoirs in which the supplies received by percolation are stored, and, to the limit of the capacity of the reservoirs, are protected from evaporation. So well are these supplies hidden that their existence was not suspected by many of the early travelers, and even to-day long desert roads without watering places lead over areas where ground water could easily be obtained.

The demand for farm homes is so great and will continue to be so great that strenuous efforts will be made to utilize by irrigation every existing water supply. The ground waters underlying the Nevada deserts will certainly receive more attention in the future than they have in the past, and costly projects for their recovery will be undertaken. Some of these projects will no doubt fail, but others will eventually be successful. So great is the eagerness for land that the report of a single flowing well or the skillful advertisements of a promoter may at any time start a stream of home seekers, ignorant of the actual conditions and difficulties, into almost any of the desert valleys of the West.

It is very desirable that the possibilities of these valleys should be thoroughly investigated before they are invaded by home seekers. The helplessness of the ordinary settler when he confronts the unfamiliar and inherently difficult problems of irrigation with ground waters is illustrated in Big Smoky Valley as well as in other areas. In the south basin of this valley (see fig. 17) there have been a few attempts at irrigation with ground water, but they were made either so far up the slopes that the high lift rendered the cost prohibitive or else in the alkali area where agriculture is not feasible; none apparently have been made in the zone in which the ground-water conditions are the most favorable.

As the ground water is hidden beneath the surface there is necessarily much uncertainty as to its occurrence, and therefore corresponding caution should be observed in regard to ground-water projects. Much can be determined as to the ground waters of desert valleys, however, even where no wells have been sunk, provided the proper observations are made and the proper criteria applied. It is generally possible to ascertain definitely where the ground water is near the surface, to outline the shallow-water areas, and to make an intelligent forecast of the depth to water in other parts of the valley. If sufficient observations are made it is also generally possible to form a rough estimate of the quantity of water that is annually available and to predict to some extent the capacity of wells, the quality of the water, and the cost of recovery. To begin to develop the groundwater supply of a valley without first investigating its groundwater conditions is as unwise as it would be to start to build a railroad 


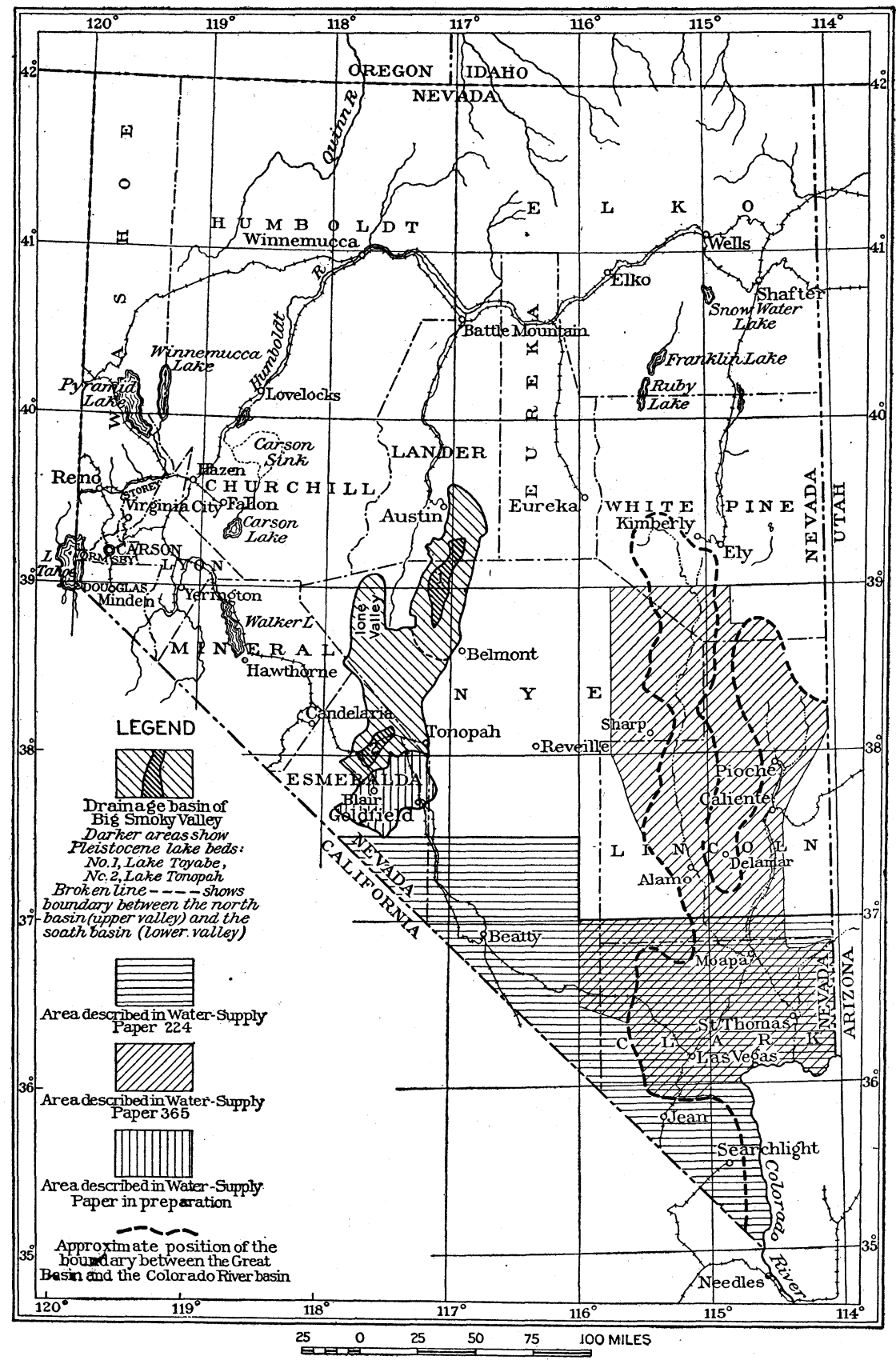

FiguRE 17.-Map of Nevada showing areas covered by water-supply papers and the Pleistocene lakes in Big Smoky Valley. 
without first having the route surveyed, and the financial results are likely to be no less disastrous.

Even where a satisfactory supply of ground water is assured irrigation may be impracticable because of the high cost of recovering the water or the unfavorable climatic, soil, or market conditions. The problem of cost must be attacked from two principal directions: (1) Means must be devised for recovering the water at the least possible expense, and (2) crops must be found, methods of irrigation and cultivation devised, and markets developed which will result in the largest possible returns from each unit of water used. In many cases different crops and different methods of irrigation and cultivation will be required with ground-water than with surface-water supplies, and for this reason the ground-water investigations of the Geological Survey should be supplemented by correlative agricultural investigations by the experiment stations.

\section{GEOGRAPHY OF BIG SMOKY VALLEY.}

Big Smoky Valley is a typical Nevada desert valley-a plain. hemmed in by mountain ranges and underlain by porous rock waste eroded from these ranges and saturated with water discharged from them. Like most of the valleys of the State, it has a general northsouth elongation and an interior drainage. The valley itself covers somewhat more than 1,300 square miles (exclusive of Ione Valley), and the entire drainage basin covers 3,250 square miles, has a length of 130 miles, and extends from about the geographic center of the State to a point less than 20 miles from the California line. The valley lies in parts of Lander, Nye, and Esmeralda counties and is crossed by the thirty-eighth and thirty-ninth parallels and the one hundred and seventeenth meridian. (See fig. 17.)

The drainage basin of Big Smoky Valley is divided by a low, gentle, alluvial swell west of Manhattan into a north basin, which contains the upper valley, and a south basin, which contains the lower valley. Each of these basins held a lake in the Pleistocene epoch and each at present contains an alkali flat. Ione Valley, which lies west of Big Smoky Valley proper and has a drainage basin of about 500 square miles, discharges into the lower valley from the northwest and hence forms a part of the south basin. The lowest point in the north basin is 5,443 feet above sea level and the lowest in the south basin is about 4,720 feet. Arc Dome, the culminating point of the inclosing mountain rim, is 11,775 feet above sea level. It is in the Toyabe Range, which forms the west edge of the north basin.

The climate is arid and exhibits the characteristic features of aridity. At a station maintained in the northern part of the valley the average annual precipitation during a period of six years was found to be 6.55 inches. In the southern part the precipitation is still less, and only on a few of the highest mountains is it considerably more. 
Owing to differences in both latitude and altitude there are appreciable differences in temperature within the region, the climate being distinctly more rigorous in the northern than in the southern part of the valley.

The drainage basin of Big Smoky Valley is sparsely populated. Tonopah, situated near its southeast corner, contains most of the inhabitants. In 1913 it was said to have a population of 7,000 and was probably the largest mining town in the State. Nearly all the rest of the inhabitants of the basin live in the mining and milling towns of Manhattan, Round Mountain, and Millers and at a number of ranches along the west side of the northern part of the valley.

Big Smoky Valley is most conveniently reached over branch lines connecting with the main line of the Southern Pacific Railroad between Oakland, Cal., and Ogden, Utah. A branch of the Southern Pacific leads from the main line at Hazen to Rhodes, where it connects with the Tonopah \& Goldfield Railroad. In 1913 Pullman cars were operated daily between Oakland and Goldfield by way of Tonopah. The Tonopah \& Goldfield Railroad also connects at Rhodes with a branch of the Southern Pacific leading to southern California by way of Owens Valley, and at Goldfield with the Las Vegas \& Tonopah Railroad and the Tonopah \& Tidewater Railroad. The Las Vegas \& Tonopah line leads to Las Vegas, which is on the San Pedro, Los Angeles \& Salt Lake Railroad. Automobile stages connect Tonopah with Manhattan and Round Mountain. The northern part of Big Smoky Valley can be reached by the Nevada Central Railroad, a narrow-gage line which connects Battle Mountain, on the main line of the Southern Pacific, with Austin, situated a few miles northwest of this valley.

Most of the ranches of this region have been in existence a long time, and their history is related to that of the mining camps to which they are tributary. As a rule they were located where small irrigation supplies could be obtained from springs or mountain streams and where consequently agriculture could be combined with cattle ranching. The principal crops are alfalfa and wild hay, but vegetables, fruits, and other foodstuffs are produced for consumption in the local markets. The revival of mining activity since the Tonopah discovery in 1900 has created new markets for farm produce and has accordingly made the ranchers more prosperous.

\section{INVESTIGATION OF GROUND WATER IN BIG SMOKY VALLEY.}

The ground water of the region was investigated by the writer in 1913 and 1914, this valley being selected not because it has exceptional ground-water possibilities but because it is believed to be more or less typical of the undeveloped valleys of the State. Only a few wells have been sunk in the valley, and practically no use has thus far been made of the ground water for irrigation. Since the inves- 
tigation was begun, however, flows have been struck in several wells drilled on the west side of the upper valley. These flows and the work of the United States Geological Survey have aroused interest in the subject of utilizing the ground-water supply. A comprehensive report with detailed maps of the valley is in preparation, but in order to meet the immediate need for information as a result of this new interest the present brief paper is published in advance of the complete report.

\section{PHYSIOGRAPHY.}

Mountains.-The upper valley is bordered on the west by the Toyabe Range and on the east by the Toquima Range. The lower valley is bordered on the north by the Toyabe and Shoshone ranges, on the east by the Toquima and San Antonio ranges, on the south by Lone Mountain, on the southwest by the Silver Peak Range, and on the west by the Monte Cristo Range.

The Toyabe, which is the largest and loftiest of these ranges, consists of an undulating upland and a steep, rugged front facing the valley. There is evidence that the undulating upland was formed by longcontinued erosion in a period when the mountains had less relief than at present, and that the steep front was produced later by faulting and uplift. The very steep front of Lone Mountain is also believed to be a fault scarp.

Altogether about 625 square miles of mountain area is tributary to the upper valley and 1,050 square miles (includirg 250 square miles in Ione Valley) to the lower valley. The mountains adjacent to the lower valley are, however, lower and more arid than those adjacent to the upper valley and they supply less water.

Alluvial fans.-Most of the surface of Big Smoky Valley consists of alluvial fans built by the streams out of the material washed from the mountains. Small gravelly fans that end abruptly and have little or no arable land are found at the mouths of the small dry canyons, and expanded, gently sloping fans are found at the mouths of the large canyons. The lower parts of the large fans contain extensive areas of excellent soil. The largest areas of good soil in Big Smoky Valley are on the lower parts of the fans of Kington Creek and the Twin Rivers, on the gently sloping surface at the north and south ends of the alkali flat in the upper valley, and on the gently sloping surface that extends northwestward from the alkali flat in the lower valley.

Ancient beaches.-In the Pleistocene epoch Big Smoky Valley contained two large lakes, one of which occupied the lowest parts of the north basin (Pl. VI) and the other the lowest parts of the south basin (Pl. VII). The ancient lake in the north basin may appropriately be called Lake Toyabe, and the one in the south basin Lake Tonopah.

Lake Toyabe at its highest level had a length of about 40 miles, a maximum width of 9 miles, and an area of approximately 225 square 


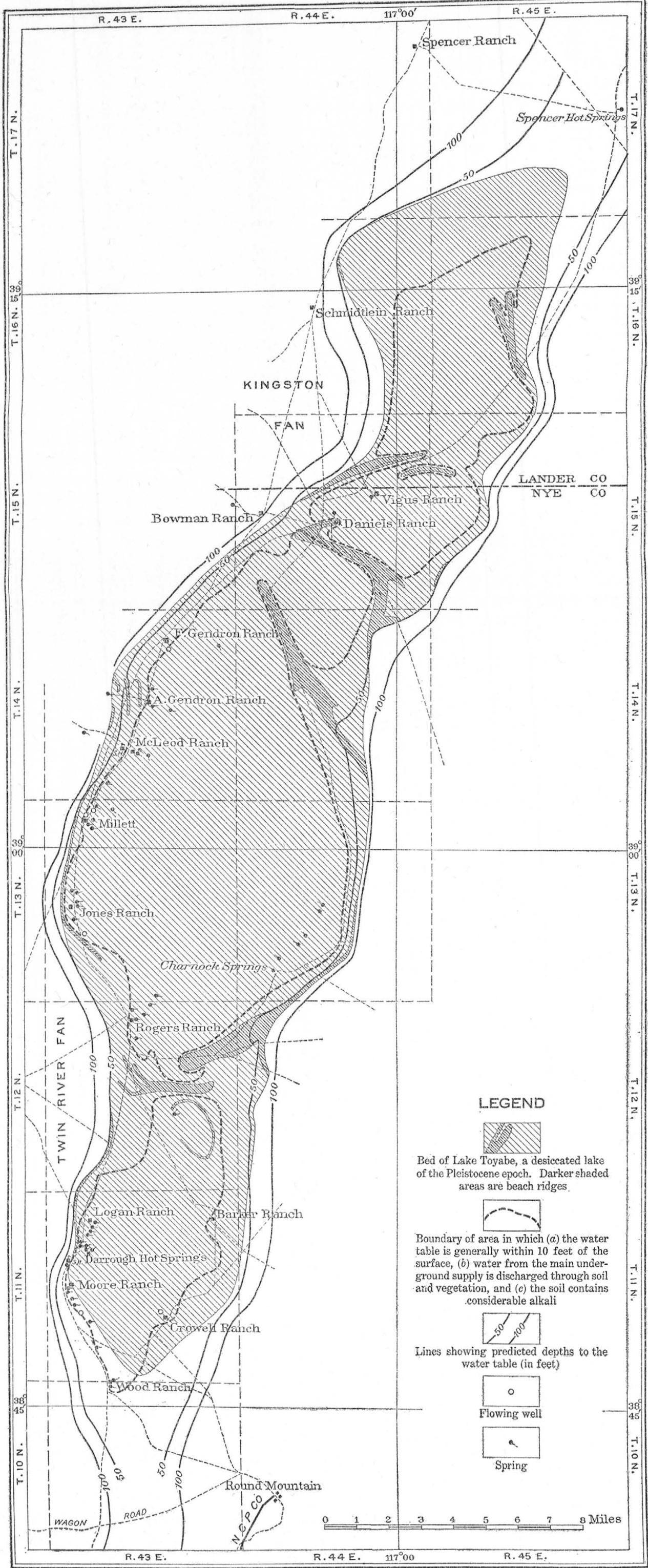

MAP OF THE SHALLOW-WATER AREA OF THE UPPER BIG SMOKY VALLEY, NEV. 


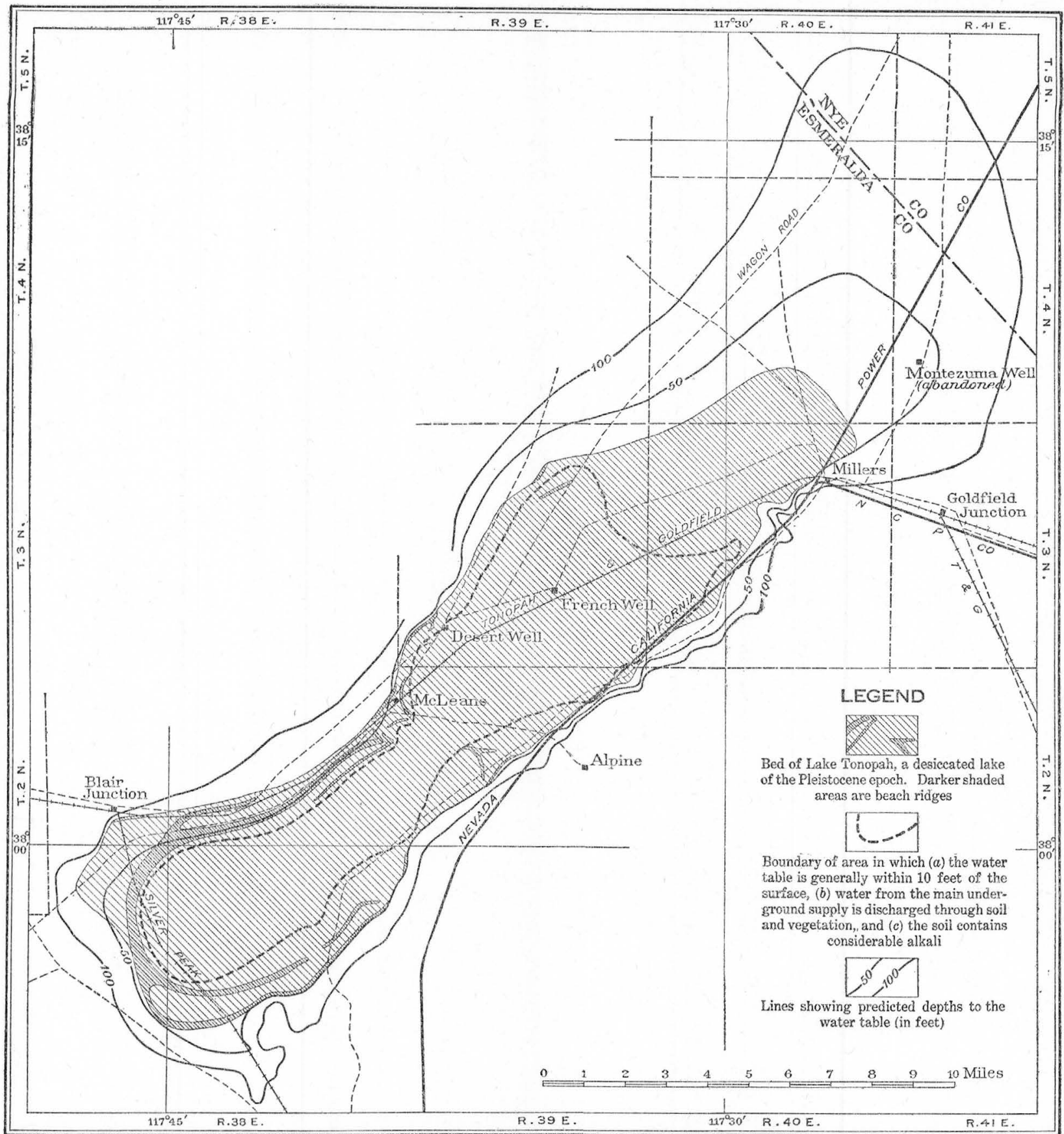

MAP OF THE SHALLOW-WATER AREA OF THE LOWER BIG SMOKY VALLEY, NEV. 
miles, or 18 per cent of the drainage basin in which it lay. Its maximum depth was about 170 feet, and its shore line, which, so far as was determined, is still horizontal, stood a short distance above the present 5,600-foot contour and measured about 85 miles in length. The maximum depth of the part of this lake that lay south of the ridges southeast of Roger's ranch was only about 70 feet. When the surface of the water went down the lake divided into two parts which were completely separated by an isthmus formed by these ridges.

Lake Tonopah at its highest recognized level had a length of about 22 miles, a maximum width of $5 \frac{1}{2}$ miles, and an area of approximately 85 square miles, or only about two-fifths that of Lake Toyabe. This area was only 4.2 per cent of the total drainage basin tributary to the lake-a percentage less than one-fourth as great as that of Lake Toyabe. The maximum depth of Lake Tonopah was about 70 feet, and its highest shore line stood a little below the present 4,800-foot contour, or about 825 feet below that of Lake Toyabe. The total length of the Lake Tonopah shore line is estimated at 53 miles.

The existence of these ancient lakes and the dimensions given in the foregoing paragraphs are deduced from the shore features which were formed by the waves and currents of the lakes and which are still in existence. These shore features consist almost entirely of gravelly beaches and beach ridges, or embankments, many of which are very definite structures that can be followed for a number of miles, the largest attaining heights of nearly 50 feet. In each basin they are found at several different levels, indicating that the surface of both lakes fluctuated. The highest discernible shore features are in positions indicating that neither lake had an outlet, even at its highest level, and it is therefore inferred that the water of both lakes was salty.

Playas.-The principal playas, or alkali flats, in Big Smoky Valley are found in the depressions occupied by the two ancient lakes. The largest extends from the Daniels ranch almost to the Rogers ranch, is nearly 15 miles long, and has a maximum width of fully 6 miles. North of the Daniels ranch a flat, interrupted by beach ridges, extends for many miles, and south of the Rogers ranch another large flat extends toward Wood's ranch. The main playa of the lower valley occupies the depression extending from the vicinity of the French well southwestward to the Silver Peak Railroad.

Fault scarps.-On the alluvial slopes east of the Toyabe Range and north and northwest of Lone Mountain there are numerous escarpments which face the valley and are believed to be due to recent faulting. In some localities there are two or three parallel escarpments with maximum displacement of more than 100 feet. Springs issue from the fault scarps back of Bowman's, Mrs. Gendron's, and McLeod's ranches, and the seepage supports a zone of vegetation that makes the scarps conspicuous as green bands. 


\section{GEOLOGIC FORMATIONS.}

\section{PREQUATERNARY ROCKS.}

Limestone, quartzite, slate, and schist, aggregating several thousand feet in thickness and ranging in age from Lower Cambrian to Carboniferous, ${ }^{1}$ are the oldest rocks found in this region. Since their deposition they have been extensively deformed, eroded, intruded by lavas, and largely covered by igneous bodies and sedimentary deposits. Originally they probably covered the entire region, but at present they are found over extensive areas only in the Toyabe, Toquima, Silver Peak, and Lone Mountain ranges. In the Toyabe Range they lie at the surface over most of the area between Birch Creek and Bowman's ranch.

- Several great bodies of granite and associated crystalline rocks occur in this region. Wherever their relations have been determined they are intrusive in the Paleozoic strata and older than the Tertiary eruptive rocks. ${ }^{1}$ Granite occurs over a large area north of Birch Creek and crops out extensively from Bowman's ranch to and beyond Wood's ranch. A large granite mass occupies the lofty central part of the Toquima Range, particularly in the region east of Round Mountain. Another large granite mass forms the main part of Lone Mountain, and granite crops out in the ridges farther southwest.

Eruptive formations of Tertiary age, consisting of rhyolite and minor amounts of basalt and rocks of intermediate composition with associated tuffs and breccias, occur over extensive areas in all the ranges bordering Big Smoky Valley. ${ }^{2}$. They lie at the surface in all or nearly all the Shoshone Range tributary to Big Smoky Valley, in the southern part of the Toyabe Range and in other localities in this range, in large parts of the Toquima Range from the north to the south end, in much the greater part of the San Antonio and Monte Cristo ranges and the hill country north of the Monte Cristo Range, and in considerable areas in the Silver Peak and Lone Mountain ranges.

Tertiary sedimentary rocks are best developed in the foothill region southwest of Lone Mountain and in the region west and southwest of Blair Junction, ${ }^{3}$.but they are widely distributed in the ranges bordering the lower valley and either crop out or lie near the surface over extensive areas in the marginal parts of the lower valley and Ione Valley. In some places there is a sharp structural unconformity between the Tertiary beds and the overlying Quaternary deposits, but

1 Emmons, S. F., Geology of the Toyabe Range: U. S. Geol. Expl. 40th par., vol. 3, pp. 320-348, 1870.

2 Spurr, J. E., Descriptive geology of Nevada south of the fortieth parallel and adjacent portions of California: U. S. Geol. Survey Bull. 208, 1903; also Geology of the Tonopah mining district, Nev.: U. S. Geol. Survey Prof. Papor 42, 1905.

s Turner, H. W., The Esmeralda formation, a fresh-water lake deposit: U. S. Geol. Survey Twenty-finst Ann. Rept., pt. 2, pp. 191-226, 1900. 
generally the contact is not well shown. The sediments are largely of volcanic origin, and many of the outcrops consist almost entirely of volcanic tuffs interbedded with thick lava beds.

\section{QUATERNARY DEPOSITS.}

The upper valley and the greater part of the lower valley are underlain by Quaternary deposits which have been only slightly deformed and have suffered very little from erosion except in the upper parts of the alluvial slopes.

As shown by the outcrops and the exposures in dug wells, the bulk of the Quaternary deposits consist of poorly assorted gravel, sand, and silt laid down by running water. Trains of gravel radiating from the mouths of the canyons are incased in a matrix of clayey material. The playas are underlain by silt and clay deposited by temporary sheets of water. These fine sediments are on most of the playas impregnated with or overlain by soluble salts. Under them no doubt lie stratified beds deposited by the Pleistocene lakes, but these beds are not exposed. Surrounding the principal flats and in some places extending across them are shore gravels deposited by the waves and currents of the ancient lakes to the maximum depths of at least 50 feet. In certain localities there are irregular deposits of sand formed by the wind. In a few places calcareous deposits, probably reaching a maximum thickness of 50 feet, have been formed by springs.

The Quaternary deposits average much thicker in the upper than in the lower valley. Although no very deep wells have been drilled in the upper valley the steepness of the adjacent mountain sides, the distinctness of the mountain boundary and the almost complete absence of rock outcrops in the valley indicate that the fill is deep. Comparison with similar valleys in which deep wells have been sunk leads to the inference that except near the mountains the fill is at least several hundred feet deep. In the lower valley the mountain boundary is less definite and rock outcrops are numerous in the valley areas. The fill is generally thin on the slope southeast of San Antonio, on the upper parts of the slopes adjacent to the San Antonio and Monte Cristo ranges, and in the southwest corner of the valley. The absence of rock outcrops in the lower parts of the slopes and on the flat, however, together with the data obtained in regard to several wells, indicates that, except near the southwest end, the fill in the axial region of the lower valley is generally a few hundred feet thick.

In character the stream deposits are directly related to the rocks from which they are derived. The slates weather into hard, black, angular fragments that are not readily rounded but yield clayey material when abraded. The limestones form abundant black pebbles that are rather resistant to weathering, but by abrasion and solution 
yield fine sediments and also calcium carbonate, by means of which the deposits become more or less cemented. The granitic rocks form arkosic gravel and quartz sand, but only small amounts of clay. The rhyolite and associated volcanic rocks, which are disintegrated chiefly by changes in temperature and frost, yield arkosic gravel and grit with only small amounts of clay and true sand. The tuffs, which consist largely of minute volcanic fragments that are not firmly cemented, weather readily, producing much fine silt.

The slate and limestone waste predominates on the Kingston fan and adjacent tracts and on the Manhattan fan and adjacent tracts and is abundant on the slope adjoining the northern half of the Toquima Range and most of the slope adjoining the Toyabe Range south of the Kingston fan. It forms only a small part of the waste in the lower valley.

Quartz sand derived from granite predominates in the axial part of the val'ey between Charnock Springs and Round Mountain, and granitic gravel is abundant on the upper part of the slope in this region. Granitic gravel and sand are also abundant on most of the slope south of Bowman's ranch and occupy almost all of the steep slope adjacent to Lone Mountain.

Grit derived from the Tertiary lavas is abundant and widely distributed. It is supplied in great quantities by the southern part of the Toyabe and Shoshone ranges, the San Antonio Range and the hills north of the Monte Cristo Range.

Fine light-colored silt that contains enough clay to bake hard when dry is a characteristic deposit of the axial parts of Big Smoky Valley and is especially abundant in the lower valley, where most of the tuff, from which it is chiefly derived, is found.

\section{PRECIPITATION.}

Careful and centinuous observations of precipitation have been made at two places in the drainage basin of Big Smoky Valley in recent years - at Tonopah, where the record is complete since August, 1906, and where the United States Weather Bureau has in recent years maintained a station, and at the Jones ranch, less than 3 miles south of Millett, where observations have been made by Fred. J. Jones since September, 1907.

Average monthly and annual precipitation (in inches) at stations in Big Smoky Valley, Nev.

[From records of United States Weather Bureau.]

\begin{tabular}{|c|c|c|c|c|c|c|c|c|c|c|c|c|c|c|}
\hline & $\begin{array}{l}\text { Length } \\
\text { of rec- } \\
\text { ord. }\end{array}$ & Jan. & Feb. & Mar. & Apr. & May. & June. & July. & Aug. & Sept. & Oct. & Nov. & Dec. & $\begin{array}{l}\text { An- } \\
\text { nual. }\end{array}$ \\
\hline $\begin{array}{l}\text { Millett...... } \\
\text { Tonopah... }\end{array}$ & $\begin{array}{r}\text { Years. } \\
6 \\
7\end{array}$ & $\begin{array}{r}0.90 \\
.54\end{array}$ & $\begin{array}{r}0.54 \\
.54\end{array}$ & $\begin{array}{c}0.51- \\
.59\end{array}$ & $\begin{array}{r}0.46 \\
.34\end{array}$ & $\begin{array}{r}0.53 \\
.30\end{array}$ & $\begin{array}{r}0.24 \\
.24\end{array}$ & $\begin{array}{r}0.87 \\
.59\end{array}$ & $\begin{array}{r}0.47 \\
.53\end{array}$ & $\begin{array}{r}0.80 \\
.60\end{array}$ & $\begin{array}{r}0.51 \\
.44\end{array}$ & $\begin{array}{r}0.31 \\
.55\end{array}$ & $\begin{array}{r}0.41 \\
.43\end{array}$ & $\begin{array}{l}6.55 \\
5.69\end{array}$ \\
\hline
\end{tabular}


The summer precipitation generally comes in the form of violent local thunder storms produced toward the close of hot days. The precipitation during the winter and early in the spring is less local and accompanies regional storms of longer duration. It forms a larger proportion of the total precipitation in the high mountains than in the valley.

\section{GROUND-WATER INTAKE.}

The ground water that lies under Big Smoky Valley is derived from the rain and snow that fall on the drainage basin. On the whole the percolation into the bedrock is unimportant, and except in a few fissures and solution channels the circulation through these formations is very sluggish. They are effectively water-tight and hold in the basin most of the water that falls upon it. The main body of ground water is in the valley fill.

Contributions to the water in the valley fill are made by (1) the permanent streams that flow out of the larger canyons, (2) the floods discharged at long intervals from the canyons which are normally dry, (3) the underflow of some of the canyons, (4) the rain that falls in the valley, and (5) a small amount of water discharged underground from openings in the rocks.

Contributions by permanent streams.-Nearly fifty of the canyons that drain into the upper valley have small permanent streams, all of which are in the Toyabe Range except five or six in the Toquima Range. The largest streams are Kingston Creek and the Twin Rivers, both of which are in the Toyabe Range. North of Kingston Creek are Santa $\mathrm{Fe}$ and Birch creeks and about ten smaller streams; between Kingston Creek and the Twin Rivers there are about eighteen small permanent streams, and south of the Twin Rivers there are eight or ten permanent streams. In the Toquima Range are North Moore, South Moore, Barker, Willow, Jefferson, and Shoshone creeks. The lower valley receives no streams except Peavine, Cottonwood, and Cloverdale creeks, which rise in the southern parts of the Toyabe and Shoshone ranges.

The streams are fed by mountain springs and also directly by rain and melting snow. Most of the springs have shallow sources, their supply being merely the seepage from the disintegrated rock near the surface. The streams are largest in the spring, when the snow melts and when there is also considerable rain in the mountains. By the end of June the snow has nearly all disappeared. In the succeeding months the evaporation is great and consequently the streams shrink rapidly. Heavy storms in midsummer occasionally swell the streams but do not contribute much to their permanent flow.

All the streams lose heavily where they flow over the alluvial slopes, and most of the water that is lost becomes a part of the underground 
supply. According to estimates based on stream measurements, ten creeks, including Birch, Santa Fe, Kingston, and Carsley creeks, were in September and October, 1914, contributing to the ground-water supply at the rate of about 7,000 acre-feet a year.

Contributions by floods from dry canyons. - All the canyons occasionally carry water in large amounts, the evidences of which may remain long after the floods have passed. Some of the floods involve large quantities of water and produce impressive results, but they occur so rarely that the average annual flood discharge is likely to be overestimated. In the south basin the floods that head in the mountains no doubt make larger contributions to the ground water than the permanent streams, but in the north basin the flood contributions are of less relative importance.

Contributions by underflow. - Since the canyons were cut they have been partly filled with porous rock waste through which water can percolate freely. Hence not all the water discharged by a canyon flows at the surface; a part flows underground and joins the main body of ground water without coming to view.

The existence of an underflow is demonstrated in many places where, owing to some underground obstruction, the watei is compelled to return to the surface, producing swampy areas or sudden increases in the stream flow, as in Willow, Peavine, and Cloverdale canyons and at the mouth of Ione Valley.

Many of the smaller canyons have no permanent underflow, and wells sunk in them would find no water. But even these, if they contain detrital deposits, must at certain times conduct considerable amounts of rain and snow water underground. The underflow is contributed to the main body of ground water with almost no loss, whereas only a part-often a very small part-of surface streams reaches the underground reservoir.

Contributions by precipitation in the valley. - The precipitation of light showers in the valley is absorbed by the capillary pores of the soil and does not make contributions to the underground supply, but the heavier rains produce streams or sheets of water which enters the earth wherever the soil is porous or fissured and which is thus added to the underground supply. If only 5 per cent of the precipitation in the valley areas joins the ground water the contribution from this source amounts to nearly 10,000 acre-feet a year in both the north and the south basin.

\section{GROUND-WATER DISCHARGE.}

Processes. - The contributions of water to the underground reservoirs are balanced by losses from these, reservoirs. The losses occur chiefly through the return of the ground water to the surface but in small part through percolation out of the basin by way of underground 
passages. The return water reaches the surface by flowing from springs or by rising through the capillary pores of the soil or the roots and stems of plants. It is all eventually disposed of by evaporation. The principal groups of springs and the areas of discharge from soil and vegetation are shown in Plates VI and VII. The principal leakage out of the basin is believed to occur at the west end of the south basin.

Discharge from springs. - The main west-side spring line of the upper valley extends, with a sinuous course due to the different sizes of the alluvial fans, from the Vigus ranch to Wood's ranch, a distance of more than 30 miles, and includes innumerable springs that discharge a part of the copious underground supply received from the Toyabe Range. On the east side of the upper valley there is no spring line comparable to that on the west side, probably because the supply from the Toquima Range is smaller than that from the Toyabe Range, but numerous springs similar to those on the west side are found for a distance of 3 miles in the vicinity of the Charnock ranch, and a group of hot springs is situated on the east side near the north end of the valley. On the alluvial slope between the main west-side spring line and the mountains a few springs flow from fault scarps and were apparently produced by impounding through dislocation of the valley fill.

The lower valley, whose ground-water contributions are smaller and less concentrated than those of the upper valley, has no spring line except such as is formed by a few water holes a short distance west of Millers. At San Antonio and the constricted outlet of Ione Valley springs are produced apparently by barriers that bring the water to the surface.

Discharge from soil and plants. - The areas in which discharge from soil or plants is taking place can be determined by observing (1) the moisture conditions of the soil and the position of the water table, (2) the appearance of soluble salts at the surface and the distribution of these salts in the soil, and (3) the distribution of certain plant species that feed on ground water.

In the areas of discharge the water table is generally within 10 feet of the surface and the ground is moist from the water table practically to the surface. Moreover, the salts that are dissolved in the water and are deposited on evaporation are generally found at or near the surface.

The principal plant indicators of shallow ground water and groundwater discharge in the mountain areas are the birch trees and willows; the principal indicators in the valley are salt grass (Distichlis spicata) ${ }_{1}$ samphire (Spirostachys occidentalis), buffalo-berry bush (Shepherdia), giant reed grass (Phragmites communis), and rabbit bush (Chryso-

1 The plant species mentioned above were, with a few exceptions, identified by Dr. P. B. Kennedy, botanist, Nevada Agricultural Experiment Station, but he is not responsible for the field interpretations. 
thamnus graveolens). Certain wild grasses used for hay or pasture also discharge ground water.

The big greasewood (Sarcobatus vermiculatus) is abundant in the shallow-water areas and in areas with moderate depths to water, where it no doubt receives a part of its supply from the main body of ground water, but it is not confined to these aros. The iodine weed (Suæda torreyana) grows in alkaline soil and is generally found where more than an ordinary supply of moisture is available, but in Big Smoky Valley it appears not to be a reliable indicator of shallow ground water, as it occurs in localities that are far above the water table. The tall shrubby salt bush (Atriplex torreyi) is not common in Big Smoky Valley, but grows here and there. It can endure considerable alkali and is generally found in low places with more than an ordinary supply of moisture, but it is not a reliable indicator of shallow water. Common sagebrush (Artemisia tridentata) is found chiefly near the bases of the alluvial slopes and along stream courses, where there are better supplies of moisture from flood waters than on the higher parts of the slopes and where the soil does not contain excessive amounts of alkali. It occupies some of the land that is most promising for agriculture. So far as known, sagebrush does not utilize water derived from the zone of saturation. It is not an indicator of shallow ground water.

The spiny salt bush (Atriplex confertifolia), of ten called shadscale, and the little, dry species of greasewood (Sarcobatus baileyi) are commonly associated and are the dominant plants on the dry slopes and plains that lie far above the water table. White sage, or winter fat (Eurotia lanata), also grows on the upland plains far above the water table.

The interior of large playas, such as the Millett and McLeans flats, are entirely barren over extensive areas. Barrenness is, however, not an indication of ground-water discharge, for it is as characteristic of some of the flats having considerable depths to water as of those having shallow water.

The largest area of ground-water discharge is in the interior of the upper valley. (See Pl. VI.) It extends a distance of 40 miles, attains a maximum width of more than 8 miles, and covers about 160 square miles, or 100,000 acres. Its northern extremity is only a few miles south of the Spencer Hot Springs and its southern extremity is in the vicinity of Wood's ranch. In all of this area the process of groundwater evaporation is uninterrupted except where the large beach ridges cross the axis of the valley. The northern and southern limits of the area are somewhat indefinite, owing to the very gradual increase in the depth to water along the axis of the valley.

The principal area of ground-water discharge in the lower valley extends from a point about $2 \frac{1}{2}$ miles southwest of Millers to a line 
just west of the Silver Peak Railroad. (See Pl. VII.) It is about 17 miles long, has a maximum width of 5 miles, and covers about 45 square miles, or nearly 30,000 acres. The northeastern limits of this area are indefinite because the increase in the depth to water in this direction is very gradual.

Quantities disckiarged.-By applying the results obtained by Lee ${ }^{1}$ on the rate of discharge in the Independence district of Owens Valley, Cal., to the conditions in Big Smoky Valley, the conclusion is reached that the average annual loss of ground water from the area of discharge in the upper valley is probably not less than one-half foot nor more than 1 foot-in other words, that the amount of water discharged from the main body of ground water in the upper valley is between 50,000 and 100,000 acre-feet a year, or between about 8 and 17 per cent of the precipitation in the north basin. These quantities are of the same order of magnitude as those derived from a study of the contributions to the underground supply (p. 96). It is estimated, on the basis of relative areas of discharge, that about 26 per cent of the discharge occurs north of the large embankment that crosses the valley just south of the Daniels ranch, about 57 per cent between this embankment and the one that crosses the valley southeast of the Rogers ranch, and about 17 per cent in the area still farther south. (See Pl. VI.)

In the lower valley the average temperature is considerably higher than in the upper valley, and over about one-third of the area of discharge, chiefly in the locality between Millers Pond and the Desert well, the porous soil and the slight depth to the water table indicate heavy loss of ground water, but over the clayey parts of the barren tract, which occupies about 7,000 acres, and over much of the western part of the area, even where there is some vegetation, the discharge is small and in some places practically negligible. The data at hand appear to indicate that the aggregate amount of ground water discharged from the lower valley is between about 10,000 and 30,000 acre-feet a year, or between about 2 and 5 per cent of the precipitation on the south basin.

It should be remembered that the estimates of both contributions and discharge are based on inadequate data, that only a part of the annual supply can be recovered through wells, and that unless the wells are widely distributed the recoverable part will form only a small proportion of the total supply. It should also be remembered that the estimates are less reliable for the lower than for the upper valley. Even for the upper valley it would not be wise to plan an initial project involving more than a few thousand acre-feet of ground water a year.

\footnotetext{
1 Lee, C. H., An intensive study of the water resources of a part of Owens Valley, Cal.: U. S. Geol. Survey Water-Supply Paper 294, 1912.
} 


\section{WATER LEVELS.}

Over an area of 160 square miles in the upper valley and an area of 45 square miles in the lower valley the water table, or upper surface of the main body of ground water, is generally within 10 feet of the surface of the ground. These shallow-water areas practically coincide with the areas of ground-water discharge, already referred to (p. 98), and are shown on Plates VI and VII. The outlines of these shallow-water areas were determined partly by examining wells and boring holes to the water table, but more largely by interpreting surface indications of shallow water afforded by the moisture in the soil, the soluble salts at the surface, and certain species of native plants (pp. 97, 98).

On all sides of each of the shallow-water areas, with possibly some local exceptions, the water table rises gradually in the direction of the mountains. In some places on the west side of the large flats in the upper valley it rises at about the same angle as the surface of the ground, and hence is within 10 feet of the surface at points more than 100 feet above the flats. In general, however, the slope of the water table is much less than that of the land surface. The lines on Plates VI and VII, showing depths to water of 50 and 100 feet, respectively, are based on determinations, from the topographic map and by the use of the hand level, of the slope of the land surface, and on reasonable assumptions as to the slope of the water table. In the lower valley there are several comparatively deep wells that give some control of the 50 and 100 foot lines, but in the upper valley there are no wells in which the water level is more than 20 feet below the surface. Although the lines showing depth to water are only forecasts and will, without doubt, be found to be considerably in error in some localities, they are believed nevertheless to be of value in directing developments.

According to the data and forecasts shown on Plates VI and VII, the areas with specified depths to water are as shown in the following table:

Estimated areas having specified depths to water table in Big Smoky Valley, Nev.

\begin{tabular}{|c|c|c|c|}
\hline Depth to water table, in feet. & $\begin{array}{l}\text { North basin } \\
\text { (upper val- } \\
\text { ley). }\end{array}$ & $\begin{array}{l}\text { South basin } \\
\text { (lower val- } \\
\text { ley). }\end{array}$ & Total. \\
\hline 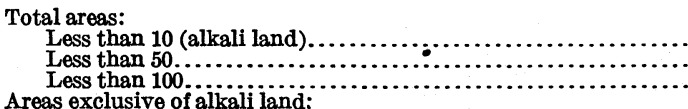 & $\begin{array}{r}\text { Acres. } \\
100,000 \\
170,000 \\
215,000\end{array}$ & $\begin{array}{r}\text { Acres. } \\
30,000 \\
70,000 \\
120,000\end{array}$ & $\begin{array}{l}\text { Acres. } \\
130,000 \\
240,000 \\
335,000\end{array}$ \\
\hline 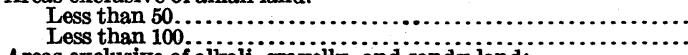 & $\begin{array}{r}70,000 \\
115,000\end{array}$ & $\begin{array}{l}40,000 \\
90,000\end{array}$ & $\begin{array}{l}110,000 \\
205,000\end{array}$ \\
\hline 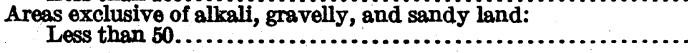 & & 20,000 & 65,000 \\
\hline
\end{tabular}




\section{WATER-BEARING CAPACITIES.}

The coarse, clean sediments derived from granite are porous and yield water freely. The arkosic grit derived from rhyolite and other igneous rocks of fine grain also generally yields water freely, but it contains more fine material, and when it disintegrates it becomes compact. The pebbles derived from the angular fragments resulting from the weathering of slate and limestone may produce porous deposits, but the pores are likely to be sealed to some extent by the cementation effected by calcium carbonate. The sediments derived from the tuffs are largely fine silt and form dense deposits that will yield little water. The sediments derived from the other stratified Tertiary rocks are also in general unpromising as water producers.

In the upper valley there are no wells that have been pumped at a rate of more than a few gallons a minute, but it is probable that in most places between the 100 -foot line (Pl. VI) and the alkali area wells yielding moderately large supplies can be obtained. In the areas adjacent to mountains in which limestone and slate predominate, as between Birch and Carsley creeks, the yields may average less than in the areas of granitic sediments, but there is no reason to believe that even in these areas wells will be failures. The most valuable water supplies will probably be found within the first few hundred feet of the surface, but it would be desirable to sink several wells to considerable depths to test possible deep-seated artesian horizons.

In the lower valley the conditions are less promising than in the upper valley because the fill is shallower and contains more sediments derived from tuffs and less derived from granite. However, there is evidence that in that part of the area having less than 50 feet to water which lies northeast of the alkali area (Pl. VII), the fill is deep enough to form a dependable ground-water reservoir. The available data as to the yields of the wells in the area northeast of the alkali area are also rather favorable. In a test of 2 hours and 40 minutes made September 1, 1913, the well of the Desert Power \& Mill Co. at Millers, which is 6 by 12 feet in cross section and about 63 feet deep, yielded at the rate of 400 gallons a minute with a drawdown of 17 feet. The well is pumped nearly half of the time and is reported to have supplied as much as 5,000,000 gallons a month. The well of the Belmont Milling \& Development Co., situated a short distance west of the Desert Power \& Mill Co.'s well, is 6 by 12 feet in cross section and about 50 feet deep. With 12 feet of drawdown it yields about 140 gallons a minute.

In the southwestern part of the lower valley the ground-water prospects are unfavorable in several respects. The Tertiary formations appear to be near the surface, and wells with large yields can 
probably not be obtained. There is a possibility of obtaining supplies by drilling into the Tertiary strata, but the prospect is too poor to make deep drilling advisable, at least until the more promising supplies from the Quaternary fill in other parts of the valley have been developed.

\section{ARTESIAN CONDITIONS.}

In the last two years seven flowing wells have been sunk in the upper valley and drilling was in progress when the valley was last visited. These wells are all in or very near the area of ground-water discharge, which has more or less alkaline soil and a depth to water not generally exceeding 10 feet (Pl. VI). The most successful one is the 127-foot well of Fred. Jones (Pl. VI), which is 6 inches in diameter and is finished with standard casing without perforations, the water entering through the open end at the bottom of the well. The first flow was struck at a depth of 68 feet, and a stronger flow was struck at 117 feet in a 10-foot bed of gravel below a layer of dense clay. The flow when measured on October 7, 1914, was 120 gallons a minute. The cost was $\$ 221$, including the casing. As shown in the table on page 114, the other wells have depths ranging from 40 to 133 feet and yields ranging from 10 to 40 gallons a minute.

The prospects of obtaining flowing wells are, as a rule, best where the water table is nearest the surface, and no money should be spent in drilling for flows outside of the 50-foot boundaries shown on Plates VI and VII. The most favorable conditions are found in the shallowwater area on the west side of the upper valley, where the slope from the mountains is steep and the water supply is abundant, but there are also prospects on the east side between the Charnock springs and Wood's ranch. To a large extent the flowing-well area will be found to be in the areas of alkali soil, but it may be possible to get satisfactory flows on some good land just outside of the alkali areas, especially at the bases of the alluvial fans of Kingston Creek, Twin Rivers, and Jefferson Creek. Even where the soil contains considerable alkali flowing wells will be profitable provided there is enough slope to make the removal of the alkali practicable, as is the case near the west edge of the alkali area in the upper valley, and provided the yield of the wells is large enough to make the cost per acre comparatively small, as is the case with the Jones well.

The conditions for obtaining flowing wells in the lower valley are believed to be less favorable than in the upper valley because the fill is not so deep, the contributions to the ground-water supply are smaller, and the principal sources of supply are farther from the shallow-water area. If any drilling for flowing wells is undertaken in the lower valley it should be done a short distance west of Millers, where the soil is fairly good but the water table is not much more than 10 feet below the surface. 
Flows could probably be obtained by drilling deep wells into the Tertiary strata in the lowest parts of the lower valley, but on account of the probable small yields and poor quality of water it is not likely that such wells would be worth what they would cost.

Waste of artesian water decreases the supply and, by reducing the yield of wells, increases the cost per second-foot of the water recovered and the cost per acre of land reclaimed with this water. This higher cost is borne in part by the man who wastes the water and in part by his neighbors. Great stupidity has been shown by the inhabitants of most flowing-well areas in their reckless disregard of obvious principles of water conservation, and it is partly for this reason that most artesian basins have proved disappointing. It is to be hoped that in the developments in Big Smoky Valley more wisdom will be exercised, and that the waste of the artesian water will be prevented by using good casing, by inserting the casing tightly through the confining beds, and by closing the wells when the water is not used.

\section{DRILLING METHODS.}

Drilling can be done with cable percussion rigs, ${ }^{1}$ mud-scnw outfits such as are used in many of the débris-filled valleys of California, ${ }^{2}$ or hydraulic rigs of either rotary ${ }^{3}$ or spudding ${ }^{4}$ type.

Cable percussion rigs are the most reliable for general exploratory work and should be used for drilling in hard formations, such as the Tertiary rocks, or in bowldery deposits, such as underlie the fan slopes in some localities. These rigs, however, are comparatively slow in operation and are not well adapted for penetrating quicksand. They will not lend themselves to the most economic development of the ground waters of the valley.

Mud scows, which are essentially bailers with heavy cutting shoes at the bottom, have been very widely and successfully used for drilling pump wells of large diameter in ordinary valley fill to obtain water for irrigation and they would no doubt be well adapted for similar use in Big Smoky Valley. They might, however, not be successful where much quicksand is encountered.

Hydraulic outfits, in which water is pumped downward through hollow drill rods and comes up on the outside, bringing the drillings with it, provide a rapid means of sinking wells in soft, fine-grained material. The rotary machines are necessarily heavy and somewhat expensive and are used in deep drilling. In machines of the other type, usually provided with expansion cutting drills, the drill rods are alternately lifted and allowed to drop, as in percussion rigs. These light, inexpensive machines are used to a considerable extent

1 Bowman, Isaiah, Well-drilling methods: U. S. Geol. Survey Water-Supply Paper 257, pp. 34-59, 1911.

2 Idem, pp. 66-70.

Idem, pp. 70-75.

4 Idem, pp. 75-78. 
for drilling flowing wells in fine valley fill and they are well adxpted for similar use in Big Smoky Valley. The wells drilled with these outfits are generally small, but there appears to be no reason why they could not be used successfully for holes 6 inches in diameter, which is the smallest diameter recommended for wells to be used for irrigation. The ascending muddy water plasters the walls of the well, producing a remarkably effective mud casing. Even in a deep well in soft material it is generally not necessary to insert casing until the entire hole has been drilled. This plastering or puddling process makes the hydraulic rigs the most successful for penetrating quicksand, but it involves the danger of shutting out valuable waterbearing beds.

The most serious difficulty that has been met in drilling in Big Smoky Valley is produced by beds of quicksand, which are always hard to handle. If the bed of sand is not too thick it may be possible to drive the casing through it into a firmer formation, or if the sand does not run too freely it may be possible to bail out enough so that the casing can be driven down little by little. Entrance of sand into the well can to some extent be prevented by keeping the well as full of water as possible, thereby producing a back pressure. Other methods of penetrating quicksand consist of (1) freezing the formation, which is too expensive for ordinary water wells, (2) inserting cement, which sinks into the quicksand and sets, after which it can be drilled through, and (3) puddling with mud by the hydraulic process. The puddling method is the most practicable for use in Big Smoky Valley.

For pump wells of large diameter double stovepipe casing, about No. 12 gage, such as is widely used in California, is probably the most economical casing that is adequate. It is commonly used in wells sunk with mud scows, where it is inserted as fast as the hole is made. In flowing wells it is advisable to use the somewhat more expensive standard screw casing. Wells in the valley fill should not be left uncased. In pump wells the casing should be perforated at every satisfactory water-bearing bed, either before or after it is inserted. Flowing wells, in order to yield the largest amounts possible, should be sunk through the entire bed that furnishes the artesian water and should have their casings perforated where they pass through this bed. Generally there are several satisfactory artesian beds below the one in which the first flow is struck, and in order to get strong flows all of them should be penetrated and the artesian water admitted by perforating the casing. Perforations may be circular holes one-fourth to one-half inch in diameter or vertical slits one-fourth to one-half inch wide. 


\section{QUALITY OF WATER.}

Analyses were made by Dr. S. C. Dinsmore of the waters from - nearly all the wells, from a number of springs and streams, and from a few test borings; also of the alkali in a number of typical soil samples. All these analyses will be published in the final report. They indicate that the waters in the upper valley, with few exceptions, contain only small amounts of mineral matter and are of good quality for irrigation; that the waters of that part of the lower valley northeast of the area of alkali soil (Pl. VII) contain larger amounts of mineral matter but are also in general good enough for irrigation, and that the waters of the southwestern part of the lower valley contain large amounts of mineral matter and are in general of poor quality or entirely unfit for irrigation.

Of the 18 samples of spring and well waters from the upper valley analyzed, seven contained less than 200 parts per million of total dissolved solids and only two contained more than 500 parts per million. The dissolved solids consist chiefly of calcium and the bicarbonate radicle. The soil analyses show that the two most injurious salts in the soil of the alkali area in the upper valley are sodium chloride and sodium carbonate, the chloride being the more abundant but the carbonate the more injurious. Within the alkali area, as shown on the map (Pl. VI), difficulty with these two salts may be expected, but not all the land within the area is irreclaimable. Indeed, a large part of the land now under irrigation with stream and spring waters lies in the alkali area and has been made fairly productive by persistent and intelligent effort. Except where the soil is already alkaline no serious alkali problem will be developed by irrigating with ground water in the upper valley.

Although the waters from the northeastern part of the lower valley (that is, the part northeast of the area of alkali soil) contain somewhat larger amounts of total dissolved solids than the ground waters of the upper valley they do not generally contain as much as 500 parts per million. They have slightly less calcium than the waters of the upper valley but considerably more sodium and somewhat more chlorine and sulphate. The quantities of all the sodium salts in the waters of the northeast province are, however, so moderate that these waters are believed to be generally satisfactory for irrigation except where the soil already contains injurious amounts of alkali. The boundary of the area of alkali soil is shown in Plate VII, but on the northeast the limits are not definite and some alkali may be encountered beyond the boundary shown on the map. "Reclamation of the land in the alkali area is not believed to be practicable, the drainage being much poorer than that of the reclaimed alkali land in the upper valley. 


\section{IRRIGATION:}

DEVELOPMENTS.

The acreage of irrigated land in the basin of Big Smoky Valley is difficult to estimate because many of the irrigated fields merge with partly irrigated or nonirrigated meadows, and these in turn merge with unproductive marsh or desert. According to estimates based on the measured or reported dimensions of fields at each ranch, the total area regularly irrigated in the basin is about 2,500 acres, of which about one-half is in alfalfa and one-half in wild grass, the acreage of all other crops being very small. In addition there is about 5,000 acres of meadow land that is occasionally flooded or naturally subirrigated and that ranges from fairly productive grass land to nearly worthless salt-grass marsh. Practically all the irrigated land is in the north basin except about 300 acres along Peavine and Cloverdale Creeks.

Most of the water used in irrigation is obtained from the numerous small mountain streams, but a part comes from valley springs along the western spring line and at the Charnock ranch. Less than 5 acres was irrigated with water from wells in 1913 and 1914. Most of the stream water is used on land near the mouths of the canyons or in open places within the canyons, but a part is led in ditches down the fan slopes and is used in the alkali area (Pl. VI) or on intermediate tracts. The meadow land and nearly all the land irrigated from springs lie within the alkali area, but the alkali has been largely removed from the best fields in this area. The tracts of good soil adjacent to the alkali area generally lie above the springs, but they could be more largely utilized than they are at present for irrigation with stream waters.

There is great loss of stream water by seepage into the porous sediments underlying the upper parts of the fan slopes. Where the water is used on the porous soil near the canyons the loss occurs largely by seepage after it has been applied to the land; where it is used on the tighter soil at lower levels the loss occurs chiefly by seepage from the ditches that lead from the mouths of the canyons to the irrigated fields several miles distant. The arroyos leading from the canyons generally have very porous soil, and to some extent loss has been avoided by using the water on the uplands adjacent to the arroyos instead of using it on the floors of the arroyos themselves, or by leading it through ditches on the upland rather than taking it down the natural streamways. Only a part of the loss, is, however, prevented by these means. The only effective methods of conserving the water supply would be (1) to prevent excessive seepage by constructing water-tight ditches from the canyons to the tracts of satis- 
factory soil, or (2) to recover the water after seepage has taken place through wells in the shallow-water areas. Both methods involve heary expenditures, but both will probably in time be used.

An experiment in waterproof ditch construction has been made by Frank Gendron, who lined with stone a ditch about 2 miles long leading from Decker Canyon to his ranch. Although no cement was used the ditch is practically watertight, as is shown by the absence along its margins of moisture or of vegetation other than the ordinary desert brush. The ditch is reported by the owner to have cost about $\$ 4,000$, all in labor, and on October 3,1914 , it was carrying only 0.64 second-foot of water. These figures suggest a high cost per unit of water developed, but it must be remembered that the flow is much less in October than in most of the irrigation season, and that without the lined ditch probably none of the supply would have reached the ranch in the later part of the season.

It is believed that improvement of ditches to prevent seepage is practicable in other places in the valley, but before any work is undertaken the bulletins on the subject of ditch construction prepared by the Department of Agriculture should be consulted and all necessary information should be obtained in order to procure the best possible results at the lowest possible cost. In some places it may be advisable to construct water-tight ditches only on the parts of the slopes that have the largest seepage losses. The installation of pressure pipe, which would not only conserve the water but would also develop power that could be used for pumping, is worthy of consideration, although its cost will no doubt in most cases be found to be prohibitive. Its use may be found economically feasible on the steep, porous upper parts of the slopes though not on the lower parts having less gradient and less seepage.

The duty of the water is also diminished by the great seasonal fluctuation of the streams. The smallest streams have their maximum flow in April, begin to dwindle in May, and fail to reach the fields before the summer is far advanced. Not only is their water totally lost during most of the summer, but the season in which a part of it reaches the fields is so brief that it is impossible to make good use of even this small supply. The larger streams reach their maxima later and maintain considerable flow throughout the irrigation season, but their seasonal fluctuations are also so great that the water in the high stages can not be utilized to good advantage. The construction of reservoirs to regulate the flow is probably impracticable for most of the streams, but no investigation of reservoir sites has been made. The development of supplementary supplies by pumping from wells has more promise of being economically feasible. 


\section{CROPS AND MARKETS.}

The short seasons, with cold springs and autumns, place a severe limit on the kind and quantity of crops that can be raised here, although this is less true of the vicinity of Millers than of the upper valley, where irrigation is now practiced. The isolation of the region places limitations on the kinds of crops that can be produced profitably. The local mining towns afford a market for hay, meat, vegetables, fruit, butter, and eggs, but this market is uncertain and easily glutted. It is of distinct benefit to the present ranchers, especially in keeping up the price of hay, but it can not be depended on to support new settlers or to make costly water-supply developments profitable.

The most valuable staple crop now raised is alfalfa, which is cut only two or three times in the season and probably has an average annual yield of not more than 3 tons an acre. At present alfalfa brings the largest returns when sold at the local mining towns, but the permanent value of this crop depends on what it is worth when fed to live stock. The cattle in the region depend largely on the range, even in the winter, but the most thrifty ranchers appreciate the value of a reserve supply of hay to supplement the range, especially in severe winters. Alfalfa requires a large amount of water, and some dependable crops could perhaps be found that would yield greater returns for the quantities of water used.

Utilization of the water supplies now going to waste would involve heavy costs and is practicable only to the extent that the developed water can do a large duty measured in financial returns. This requires crops of as high value as possible for the amount of water that they consume, cultural methods that will be as sparing as possible of the water supply, and arrangements by which the developed water can do extra duty in supplementing existing irrigation supplies. Much can no doubt be accomplished along these lines if systematic experimentation is undertaken by the State experiment station

\section{IRRIGATION FROM WELIS.}

WELLS.

Irrigation can be accomplished with water from flowing wells and with water pumped from nonflowing wells. Where flowing wells are utsed the expenditures for the wells and for reservoirs adequate to hold the supplies of about one day are practically the only items of cost that are chargeable to the water supply; where pumped wells are used the cost of the water includes not only the expenditure for the wells but also the cost of the pumps, engines, or other sources of power, and necessary equipment, together with the operating expenses, which include fuel, lubricating oil, attendance, and repairs. However, in most valleys similar to Big Smoky Valley that have been 
thoroughly tested flowing wells are obtained only in restricted areas, often where the soil is poor, and their yields are relatively small; hence extensive developments are likely to require the installation of pumping plants.

Flowing wells are preferably finished with standard screw casing, 6 to 8 inches in diameter. Where flows are not expected the double stovepipe casing is adequate and somewhat less expensive and can be used in sizes ranging from 8 to 12 inches in diameter. The depths to which it is advisable to sink irrigation wells differ with different localities and range from less than 100 feet to several hundred feet. In some localities a given quantity of water is developed at the lowest cost by sinking one rather deep well; in others the same quantity is developed at the lowest cost by sinking two or more shallow wells. If, however, two or more wells are sunk in the same locality they should for the sake of economy in operation be connected, if practicable, with the same pump. Great pains should be taken to develop the largest possible yield from every well by having the casing perforated at every satisfactory water-bearing bed with as many and as large perforations as is practicable, and by cleaning the well thoroughly by heavy pumping in order to remove the fine sediments and to produce a gravel strainer around the casing. Large yields not only keep down the cost for well construction per unit of water developed, but they also, by diminishing the drawdown, keep at a minimum the cost of lifting the water.

\section{PUMPS.}

Horizontal centrifugal pumps are in general the best pumps for lifting irrigation supplies from wells in areas where the water table is not far below the surface. As only shallow-water areas are at present to be considered for reclamation by means of well water these pumps are recommended for use in Big Smoky Valley. They should be set in pits just above the high-water level and should draw from the wells by suction. If a pump is not supplied, with this manner of installation, by the well from which it draws, additional wells should be sunk and fitted with suction pipes that connect with the pump. The yield should, if possible, be determined by means of a temporary -installation before the permanent outfit is bought and installed. Yields of at least 100 gallons a minute from a well should be obtained in order to have a development that is fairly economical. A single well with a capacity of 100 gallons can be pumped with a small centrifugal pump for the irrigation of 10 to 15 acres, but the cost per acre-foot of water will be less if several such wells are sunk about 50 feet apart and all are drawn upon by a single pump of larger capacity. Of course, if each of a group of five wells yields 100 gallons a minute when pumped alone the total yield of all pumped simultaneously will, 
on account of mutual interference, aggregate considerably less than 500 gallons a minute. In some parts of the valley yields of several hundred gallons a minute can no doubt be obtained from a single properly constructed well.

The cost of pumping water depends largely on the efficiency of the pump and other machinery, and the efficiency depends on numerous mechanical details. These are better understood by the mechanic than by the farmer, but they must be mastered by every farmer who hopes to make a success of pumping for irrigation. They are subjects of general application which can not be adequately discussed in this paper, but are admirably treated in a booklet by Charles A. Norcross. ${ }^{1}$ Most of the manufacturing firms have in their service engineers or expert mechanics who will assist farmers in planning installations suited to their particular needs.

\section{POWER.}

The cost of the power is usually the largest single item in the cost of pumped well water. With a given efficiency the amount of power necessary to pump an acre-foot of water is directly proportional to the height to which the water is lifted. When the pump is operated the water surface in the well is drawn down from its normal level to some lower level, where it usually remains approximately stationary while the pump is running, but when the pump is stopped the water in the well returns about to its normal level. The total lift is the distance from the water level while the pump is in operation to the level of the outlet of the discharge pipe; that is, it is the depth to the water table plus the drawdown. If the depth to the water table is 25 feet and the drawdown with a certain rate of pumping is 15 feet, the total lift is 40 feet.

Possible sources of power that may be considered for irrigation pumping in Big Smoky Valley are (1) distillate used in small internalcombustion engines installed at the individual pumping plants, (2) electric current from commercial power lines, (3) electric current produced by a central power plant using crude oil or other fuel shipped into the valley, (4) electric current produced by a power plant at the coal mines near Blair Junction, and (5) electric current produced from local water power.

- The most practical source of power during the experimental stage of pumping is the gasoline engine using distillate for fuel. The installation should be approximately as shown in figure 18 . A shelter should be made for the engine and well and they should be protected from floods.

The approximate cost of fuel if distillate is used is shown in the following table adapted from the bulletin by Norcross: ${ }^{2}$

1 Irrigation pumping in Nevada: Nevada Bur. Ind., Agr., and Irr. Bull. 8, 1913. 2 Idem, p. 37, 
Cost of distillate, at 15-cents a gallon, for pumping, based on 35 per cent efficiency of the pump and drive, with an engine developing 1 horsepower-hour on one-seventh gallon.

\begin{tabular}{|c|c|c|c|}
\hline $\begin{array}{c}\text { Pumping } \\
\text { lift. }\end{array}$ & $\begin{array}{c}\text { Distillate } \\
\text { required to } \\
\text { pump 1 acre } \\
\text { foot of water. }\end{array}$ & $\begin{array}{c}\text { cost for 1 } \\
\text { acre-foot of } \\
\text { water. }\end{array}$ & $\begin{array}{c}\text { Annual cost } \\
\text { for water for } \\
\text { 1acre assum- } \\
\text { ing a depth of } \\
\text { irrigation of } \\
\text { 2. feet a } \\
\text { season. }\end{array}$ \\
\hline Feet. & Gallons. & & \\
10 & 5.6 & $\$ 0.84$ & $\$ 2.10$ \\
20 & 11.2 & 1.68 & 4.20 \\
30 & 16.8 & 2.52 & 6.30 \\
40 & 22.4 & 3.36 & 8.40 \\
50 & 28.0 & 4.20 & 10.50 \\
\hline
\end{tabular}

According to the schedule of rates for industrial power, effective March 5, 1914, in the region in which Big Smoky Valley is situated,

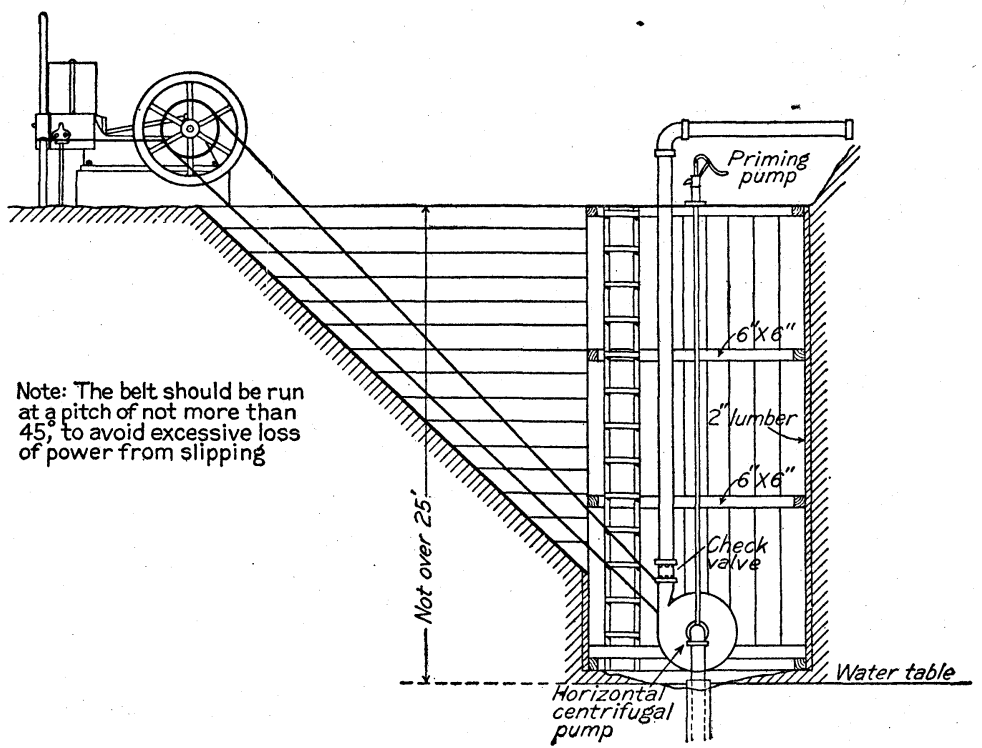

FrguRE 18.-Diagram of a pumping plant adapted for conditions in Big Smoky Valley, Nev., consisting of a horizontal centrifugal pump driven by a gasoline engine. (After C. A. Norcross.)

the charge for electric current is $3 \frac{1}{4}$ cents per kilowatt-hour if less than 1,000 kilowatt-hours is used in a month, and according to a sliding scale with somewhat lower prices if more current is used. The efficiency of an electrically driven plant is somewhat greater than that of a plant operated by a gasoline engine. The cost of power in an electric plant with an efficiency of 40 per cent, including the motor, at a charge for current of $3 \frac{1}{4}$ cents per kilowatt-hour, is almost the same as the cost given in the above table for a typical plant using distillate at 15 cents a gallon. An electric plant has an important advantage over one driven by a gasoline engine in requiring less attention and less skill on the part of the farmer. 


\section{2}

CONTRIBUTIONS TO HYDROLOGY OF UNITED STATES, 1915.

The line of the Nevada-California Power Co. crosses the area having less than 50 feet to water in the lower valley (Pl. VII) and runs to Round Mountain, which is less than 5 miles from the similar area in the upper valley (Pl. VI), but an extension of many miles would be required to bring the current to the northern part of the shallowwater area of the upper valley. If satisfactory water supplies are developed in the vicinity of Millers and at the south end of the shallow-water area of the upper valley, pumping with electricity could first be tried in these two localities, and if the experiment proved successful the transmission line could later be extended.

Crude oil is delivered at Millers in carload lots for about 4 cents a gallon. A well-equipped central plant using this fuel and connected by electric lines with pumping units could no doubt supply power at less cost than the small gasoline engines installed at the pumping units. Power could probably also be developed at relatively low cost if a plant were built at the Coaldale coal deposits, a few miles southwest of Blair Junction. These deposits have been described by J. H. Hance, ${ }^{1}$ of the United States Geological Survey, who makes the following statement:

The analyses show that the coal has a high heat value and is bituminous, but this desirable feature is partly offset by a high percentage of ash-making constituents. The coal keeps well, slakes very little, and may meet an economical and efficient use in the gas producer. By using it as a gas coal, a power plant might be established at the mines and the neighboring towns and camps supplied with electric power more cheaply than under present conditions. However, it probably will not bear transportation charges, such as prevail in this State, and can scarcely hope to have extensive use as a domestic fuel.

No power plant should, however, be constructed until irrigation with ground water has passed beyond the experimental stage and a supply large enough to justify the necessary expenditure has been developed.

The streams that discharge into the upper valley have steep slopes and great head, but the quantities of water they carry are small, especially in the later part of the summer. The cost of developing water power from these streams for pumping would probably be prohibitive, but the matter is worthy of investigation. According to current-meter measurements made October 1, 1914, Kingston Creek flowed 6.68 and 7.21 second-feet at two points $3 \frac{1}{2}$ miles apart and having a difference of elevation estimated at not less than 800 feet. During most of the irrigation season the flow is no doubt considerably greater. With an over-all efficiency of $33 \frac{1}{3}$ per cent, the power from $7 \frac{1}{2}$ second-feet of water falling 800 feet would lift 50 second-feet of well water from a depth of 40 feet. At $\$ 3,000$ per second-foot the value of this amount of water would be $\$ 150,000$. 
cost.

The most uncertain item in the initial cost of a pumping plant is the cost of the wells, the uncertainty in this item being due to the large local variations in the depth and yield of water-bearing beds and the impossibility of predicting the depth and yield accurately. If a well 100 feet deep yields 450 gallons a minute, and the drilling and casing cost $\$ 2$ a foot, the cost for this item is only $\$ 200$ per secondfoot, but if a well 200 feet deep yields only 100 gallons a minute, the cost, at the same rate for drilling and casing, is $\$ 1,800$ per second-foot.

If the cost of a pumping plant with a capacity of 1 second-foot is $\$ 1,200$, including wells, pump, engine, and accessories, the interest on the investment at 7 per cent amounts to $\$ 84$ a year, and the depreciation and repairs, reckoned at 10 per cent of the initial cost, amount to $\$ 120$ a year, making the annual charge for interest, depreciation, and repairs amount to $\$ 204$. If the plant is operated an average of 15 hours a day for 120 days, it will yield 150 acre-feet during the irrigation season. The charge for interest, depreciation, and repairs will therefore, on these assumptions, be $\$ 1.36$ for each acre-foot of water. This charge must be added to the cost of operation in order to ascertain the total cost of the water.

If the cost for fuel to generate power is as shown in the table on page 111 and the total lift is 40 feet, the cost for each acre-foot will be $\$ 3.36$ plus $\$ 1.36$, or a total of $\$ 4.72$, exclusive of labor, lubricating oil, taxes, and the conducting and applying of the water to the fields. This is the cost of the water delivered by the pump and does not take account of any loss in storage or distribution. On the above assumptions, disregarding loss, the annual cost for power, interest, depreciation, and repairs will amount to $\$ 11.80$ an acre if $2 \frac{1}{2}$ feet of water is applied during the irrigation season. With this duty of water the hypothetical plant would irrigate 60 acres at an annual cost for fuel of $\$ 5.04$.

If electric current is obtained from the Nevada-California Power Co., the cost will be about the same as calculated above. If there is poor success with the wells, if the lift is higher, if more expensive fuel is used, if there is a poor installation or unskillful operation of pump and engine, if there are frequent breakdowns, or if more water is required per acre, the cost will be greater than calculated above. If there is very good success with the wells, if the lift is less, if power is produced on a large scale in the most economical manner possible, if the efficiency of the plant is by skill and care kept unusually high, or if by good methods of irrigation and cultivation or the wise selection of crops the duty of the water is increased, the cost per acre may be reduced to a somewhat lower figure than calculated above 
It is obvious that at present pumping for irrigation is economically practicable only for raising high-priced crops and for raising ordinary crops in localities with exceptionally favorable conditions. The principal favorable conditions referred to are (1) soil that is not injuriously alkaline, sandy, or gravelly, (2) small depths to the water table (not much more than 10 feet), and (3) water-bearing beds at moderate depths that will yield freely.

In the following table are given the estimated costs of the water thus far developed from flowing wells, the cost of drilling and casing being calculated at the same rate as in the Jones wells (p.102) although the actual cost for some of the wells was greater:

Estimated cost of irrigation water developed from flowing wells in Big Smoky Valley.

\begin{tabular}{|c|c|c|c|c|c|c|c|}
\hline \multirow[b]{2}{*}{ Owner. } & \multirow[b]{2}{*}{$\begin{array}{l}\text { Depth of } \\
\text { well. }\end{array}$} & \multirow[b]{2}{*}{$\begin{array}{l}\text { Cost of } \\
\text { well. }\end{array}$} & \multicolumn{3}{|c|}{ Yield. } & \multicolumn{2}{|c|}{ Cost. } \\
\hline & & & $\begin{array}{l}\text { Gallons } \\
\text { per } \\
\text { minute. }\end{array}$ & $\begin{array}{l}\text { Second- } \\
\text { foot. }\end{array}$ & $\begin{array}{c}\text { Acre-feet } \\
\text { per season } \\
\text { of } 150 \text { days. }\end{array}$ & $\begin{array}{l}\text { Per } \\
\text { second- } \\
\text { foot. }\end{array}$ & $\begin{array}{l}\text { Per acre- } \\
\text { foot, inter: } \\
\text { est at 7 per } \\
\text { cent and } \\
\text { deprecia- } \\
\text { tion at 10 } \\
\text { per cent. }\end{array}$ \\
\hline 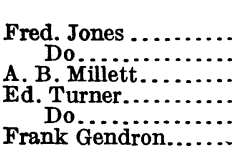 & $\begin{array}{r}\text { Feet. } \\
127 \\
68 \\
101 \\
90 \\
40 \\
? 133\end{array}$ & $\begin{array}{r}\$ 221.10 \\
112.20 \\
167.00 \\
148.50 \\
66.00 \\
? 219.45\end{array}$ & $\begin{array}{r}120 \\
30 \\
40 \\
30 \\
? 10\end{array}$ & $\begin{array}{r}0.267 \\
.067 \\
.089 \\
.067 \\
.022\end{array}$ & $\begin{array}{l}79.4 \\
19.8 \\
26.5 \\
19.8 \\
? 6.6\end{array}$ & $\begin{array}{r}\$ 825 \\
1,675 \\
1,870 \\
3,200 \\
29,975\end{array}$ & $\begin{array}{r}\$ 0.47 \\
1.96 \\
1.84 \\
25.65\end{array}$ \\
\hline
\end{tabular}

The depreciation will be found to vary greatly in both pumping plants and flowing wells, and the estimate of 10 per cent a year for this item is quite arbitrary. The depreciation will probably be as great in flowing wells as in pumping plants, but it will involve different factors. It will not include the wear and tear of pumps and engines, but it will include the gradual diminution in yield that characterizes the history of many flowing wells, especially where there is much development.

The above table shows that in the areas where flows of any consequence can be obtained the cost of artesian water is much less than the cost of pumped water. Flowing wells can profitably be sunk to procure water for irrigation in all such areas even though the soil may contain undesirable amounts of alkali, as is generally the case where flows are obtained. However, the satisfactory flowing-well areas will no doubt be found to be small and easily overdeveloped, and the reclamation of any considerable amount of land will probably be possible only by pumping. 
AREAS.

The areas that are best adapted for the development of groundwater supplies for irrigation in the upper valley are shown as nearly as is possible in Plate VI. The tracts best adapted for pumping lie within the area that is bounded on one side by the area of alkali soil and on the other by the lines indicating a depth to water of 50 feet.

Beginning in the axial part of the valley east of Spencer's ranch, the principal tract widens southward till it reaches the alkali area, thence it extends as a broad belt along the northwest flank of the alkali area to the latitude of Schmidtlein's ranch, thence as a narrower belt on the west side of the alkali area nearly to Millett, where it becomes very narrow. From the Jones ranch it extends as a belt of moderate width nearly to the Logan ranch, where it again becomes very narrow. A short distance south of Moore's ranch it expands into a belt of moderate width and thence extends to Wood's ranch and southward, for at least several miles, along the axis of the valley. It also includes a belt on the east side of the alkali area that extends northward to the Crowell ranch. A few small tracts may be found in other localities on the east side. The areas most promising for irrigation with artesian water are the lower parts of the tract just outlined and also small parts of the alkali area, especially along its west margin.

The area best adapted for pumping in the lower valley is in the vicinity of Millers and is shown on Plate VII as bounded on the southwest by the alkali area and on its other three sides by the lines indicating a depth to water of 50 feet. If any flowing wells of value for irrigation are obtained in the lower valley they will probably be in the lower part of this area, but the prospects even there are not especially good. The rest of the lower valley is practically without prospects.

\section{CONCLUSIONS.}

1. Several tens of thousands of acre-feet of ground water is probably annually available for irrigation in Big Smoky Valley.

2. Most of this supply is in the upper valley, but a part is in the vicinity of Millers in the lower valley.

3. The water is in general of satisfactory quality for irrigation. Nearly all of the poor water is in the southwestern part of the lower valley; where there is practically no prospect for irrigation.

4. A small part of the ground-water supply can be recovered by means of flowing wells, but full use of the supply can be obtained only by pumping.

5. Throughout the extensive areas in which the depth to the water table does not exceed 10 feet the soil contains injurious amounts of alkali. 
6. In the areas in which the depth to the water table ranges between 10 and 50 feet there is enough good soil to utilize all the groundwater supply. These areas, however, also contain considerable gravelly, sandy, and alkaline soil.

7. There are some prospects of obtaining flowing wells wherever the water table is near"the surface, but the prospects are best on the west side of the upper valley.

8. The flowing-well areas will be found to lie chiefly within the areas of alkali soil, but they may extend into adjacent areas of good soil.

9. Full development of the ground-water supply for irrigation will not be economically practicable until cheaper power or more valuable crops can be introduced than are now in sight.

10. Developments believed to be practicable at present are (1) the sinking of flowing wells of moderate depths in the restricted areas where fairly copious flows can be obtained and the soil is not irreclaimably alkaline, and (2) the sinking of nonflowing wells and the installation of pumping plants for raising high-priced crops and for raising ordinary crops in localities where the conditions are exceptionally favorable or where the well water can be used to supplement surface-water supplies.

11. The raising of high-priced crops is practicable to only a small extent. Vegetables and small fruits could, it is believed, be profitably raised in the vicinity of Millers to supply Tonopah, Goldfield, and other local markets.

12. The principal favorable conditions that are necessary in order to make pumping profitable for raising ordinary crops, such as alfalfa, are soil that is not injuriously alkaline, sandy, or gravelly; small depths to the water table (not much more than 10 feet); and water-bearing beds at moderate depths that will yield freely.

13. Ground-water developments along some of the lines indicated could well be made by the ranchers now in the valley, who could afford to take some chances and who could advantageously use the well water to supplement their fluctuating surface-water supplies.

14. A small number of new settlers could probably make a livelihood by irrigating with ground water in Big Smoky Valley, provided they had a few thousand dollars each to make the necessary developments and used good judgment as to locations.

15. Existing conditions do not warrant the influx of a large number of settlers nor of any without means to sink wells and make other necessary improvements. Ill-advised immigration will inevitably lead to disappointment and suffering. 